\title{
NECTIN1 wt Allele
}

National Cancer Institute

\section{Source}

National Cancer Institute. NECTIN1 wt Allele. NCI Thesaurus. Code C118613.

Human NECTIN1 wild-type allele is located in the vicinity of 11q23.3 and is approximately $106 \mathrm{~kb}$ in length. This allele, which encodes nectin-1 protein, is involved in both viral entry and the promotion of cell-cell adhesion. Mutation of the gene is associated with both cleft lip/palate-ectodermal dysplasia syndrome and orofacial cleft 7. 